\title{
SYSTEMATIZATION OF THE MAIN THREATS TO THE INFORMATION SECURITY OF A STATE ${ }^{1}$
}

\author{
I.S. ROMANCHENKO \\ Borysfen Intel - Ukraine \\ V.I. HVOZD \\ Borysfen Intel - Ukraine \\ Colonel O.I. SOLOMITSKY \\ Borysfen Intel - Ukraine
}

\begin{abstract}
Over the past few years, Ukraine has faced other countries' building up information influence. In this regard, relevant is the issue of identifying and systematizing threats to the state's information security, as well as ways to counteract them. The article identifies and systematizes the threats to the country's information security and proposes the main directions of counteracting them.

Key words: information security, information support, information war, military security, security and defense sphere, telecommunication systems, threats, Ukraine.
\end{abstract}

The Problem in general. The security issue at the beginning of the $21^{\text {st }}$ century has become universal. In addition to the traditional military and military-political spheres, it has permeated the spheres of social, economic, legal, cultural, environmental and information relations.

Over the past few years, Ukraine has faced other countries' building up information influence. Unfortunately, our state was unable to adequately respond to threats in the information sphere. This has led to a significant reduction in the level of national and, in particular, military security of Ukraine.

However, despite the growing information pressure, we still are not paying enough attention to building up our own military information potential, development of information means of military policy and strengthening of the information component of the security and defense sphere.

In this regard, relevant is the issue of identifying and systematizing threats to the state's information security, as well as ways to counteract them. Lately, researchers in other countries, in particular in Russia [1-4], and our domestic scientists [5-7]

1 The authors - prof. I.S. Romanchenko, dr. V.I. Hvozd, and dr. Col. O.I. Solomitsky hold degrees in the Military sciences, and are the analysts of the Borysfen Intel - Independent Analytical Center For Geopolitical Studies, based in Ukraine (borysfenintel@gmail.com). 
have been paying great attention to the issues of information struggle, detecting and counteracting the threats in the information sphere. However, the subject-matter of identifying (systematizing) the threats and ways of counteraction has not been completed yet, especially in the light of the events of the past three years.

Therefore, the objective of this article is to identify and systematize the main threats to Ukraine's security in the information sphere, as well as the main directions of counteraction them.

Presenting the main material. In the modern world, the role of the information component during the political and military confrontation of the states has grown significantly. Ukraine, almost since the time of independence, has been under the powerful informational influence from Russia and the West, which are trying to achieve their own geopolitical goals in the region. Therefore, ensuring information security, which determines the military and national security of the country as a whole, is a very important task.

For the fulfillment of the vital task of the state - to protect the sovereignty and territorial integrity of the country, it creates forces, means and bodies capable of fulfilling this task by joint efforts. Their work, united by common goals, tasks and methods of implementation, is based on a single legal basis and general principles of ensuring national security and is carried out in a unified strategic management style.

The combination of these forces, means and bodies creates a system for ensuring Ukraine's military security. It is the most important and the only state mechanism designed to implement the country's conceptual views and doctrinal guidelines in the sphere of military security. This task is realized through the coordination of activities of the executive and legislative authorities, local self-government bodies, public associations, and individual citizens in accordance with the current legislation.

The main role of the military security support system in the structures of state power and management lies in the system's strict tying the national interests, values and goals of Ukraine with the political course of the state, all sorts of threats of a military character, and the forms and methods of their implementation mainly with the help of political-military and military methods.

The military security support system can have external and internal aspects. From the point of view of the external aspect, this is first of all the ability of the Armed Forces of Ukraine, other military formations and bodies, military infrastructure and intelligence, counter-intelligence, information and other security support systems to contain (prevent) an open military aggression against Ukraine and its allies.

From the point of view of the internal aspect, it is the creation and development of a military organization of the state ensured by real economic capabilities of the country. 
The military security support system covers virtually all areas of the functioning of the society and state, most important of which, according to military experts and scholars, are:

- the military sphere (the issue of improving the military organization of the state, defense planning, operational and combat training of troops and forces);

- military-political sphere (issues of collective regional and global security, peacekeeping activities);

- military-economic sphere (issues of economic and resource support to military building, maintenance of activities of troops and forces at the level providing the required degree of combat readiness and combat capability, the issue of forming a military budget and allocating budget funds);

- military-social sphere (issues of the spiritual and ethical preparation of the population to the resolving defense tasks, ethical and psychological problems of military collectives, social problems of military servicemen);

- military-technical sphere (development of fundamental science for the benefit of the defense of the country, studies and applied researches, basic military technology, issues of the creation, modernization and utilization of samples of weapons and military equipment, training of specialist, scientific and technical personnel);

- military-technological sphere (development of basic military technologies for fulfilling operational-strategic, operational and operational-tactical tasks - improvement of intelligence and command and control systems, intelligence-strike systems, etc.);

- the legal sphere (arms and disarmament control);

- sphere of military-technical cooperation (export control, formation of the nomenclature of exports of arms and military equipment, system of training personnel and other types of support);

- sphere of normative and legal support of military building (improvement and development of the relevant legal framework).

The military security support system ensures a combination of centralized and decentralized management of forces and means in accordance with the unitary system of Ukraine, hence a clear division of powers between the state authorities of Ukraine, its subjects and local self-government bodies.

At the same time, of special importance in ensuring military security is the process of preparing and taking forward-looking decisions to protect national interests.

Since any decisions, especially in the sphere of ensuring national security, is based on information, it is on the state of the information support to the military security that its general level depends. 
In our opinion, the information support to military security is a complex of measures for collecting, accumulating and analyzing the information necessary to identify the current state and forecast of the development of military security and decision making in the sphere of defense of Ukraine's military security.

In turn, the system of identification (assessment) of the state of military security is a hierarchical set of interrelated indicators and criteria that allows to get a comprehensive characteristics of the current state, identify sources of real and potential threats, and forecast the development of military security.

Ensuring the safety of a person, society, country and the environment is closely linked with the identification of a set of factors, assessment of their negative effects and comparing the influence of different factors on the objects of security. So, military security should be based on a system of criteria that let draw conclusions about the degree of danger of a particular influence.

The military security criterion is a comprehensive comparative assessment of the state of military security of the country in terms of the most important processes, phenomena, parameters that reflect its essence. The criterion is a qualitative assessment, on the basis of which the level of military security is adequately determined.

The security criteria require choosing certain indicators of the military security of the research object. But for assessing the safety status, important are not the indicators themselves, but their limit values.

Limit values - the upper and lower limits, non-compliance of which interferes with the normal development of a person, society, country and the environment and leads to formation of negative, destructive trends.

The concept of dynamic stability is closely related to the mechanism of homeostasis, the mechanism of preserving the invariance of some essential characteristics of safety systems, regardless of external influences. Therefore, the first necessary step of any systemic studies of national security should be the definition of the limits, that is, the critical values of the parameters of different security spheres. The second step of research should be to study the reaction of the system to its deviation from the homeostatic limit. Thus, the relationship between safety indicators and threshold values should be considered in dynamics, and in case of significant deviation from them, they should be carefully studied.

The mechanism of homeostasis determines the conditions for a safe existence of the country as a whole. After all, it is the understanding of security as a situation where vital interests of a person, a society, a country are protected against all sorts of threats, that needs determination of limit values of negative influences on objects of security that would not lead to their death or degradation. Without knowledge of the limits of safe living conditions, the protection of vital interests of security objects is impossible. 
Each system has parameters that are essential and vital for it, the parameters on which depends the answer to the question whether the system itself exists. The homeostasis of the system preserves exactly these parameters and thereby supports the existence of the system. There are two types of homeostasis: systemic (general), which ensures preserving integrative (integral) quality, and partial - by its separate component.

Taking this into consideration, the safety of complex systems should be seen as the phenomenon identical to homeostasis of the system. By the latter is usually meant such a state of dynamic stability of complex self-regulating systems, which is intended to keep the most important for preserving the system parameters within the permissible limits.

The indexes (indicators) of military security, through which the limit values are determined, form a system of indicators of military security. The highest level of military security is achieved where all military security indicators are within the permissible limits of their limit values, and the limit values of one indicator are achieved without detriment to others.

Thus, the level of military security can be assessed through a system of its criteria and indicators.

So, the improvement of the system of monitoring Ukraine's military security by introducing indexes (indicators) of military security, collecting, processing and analyzing information on the development of the situation in different spheres of military security by the determined indexes (indicators) of its state, assessing the situation, forecasting its development and possible negative consequences remains the most urgent issue in the system of information support to Ukraine's military security.

Without the development of appropriate indicators and criteria it is impossible to objectively assess the state, let alone make a forecast for the development of Ukraine's military security. As a result, it is virtually impossible to work out well-grounded proposals for the military-political leadership of our country in adopting forward-looking decisions to protect national interests in the military sphere.

In order to substantiate the above-mentioned proposals, a system of the information support to military security should be established in the country under which it is proposed to understand the totality of the relevant governing bodies, subunits of ministries and departments, non-state institutions (with information and analytical capabilities for analyzing the threats to military security of the country in the military sphere), with functions, established by regulatory legal acts, for the search, collection, analysis, processing, accumulation and transferring of information to government bodies authorized to conduct state policy in the military security sphere.

One of the functions of the information support to military security is taking measures to maintain information security. 
Given the rapid formation and development of the information society and the global information space, the widespread use of information and communication technologies in all spheres of life, and also taking into consideration the military-political situation that has developed in Europe as a whole and in Ukraine, in particular, the problems of information security are becoming more and more important.

As a result of the lack of an effective system of the support to information security in Ukraine's national information space, there are a number of negative phenomena that create real and potential threats to the information security of a person and citizen, society and the state.

As you can see, the importance of the information component is growing and it is becoming one of the most important elements of ensuring military and national security. Information space, information resources, information infrastructure and information technologies have a significant impact on the state's ability to counter military threats.

Therefore, it can be stated that the level of development of the information space and its security actively influence the state of political, economic, defense and other components of the national security of Ukraine.

Thus, information security is an integral part of each of the spheres of national security, in particular - of the military one.

That is why the maintenance of an appropriate level of military security of the state is possible only if a proper level of information security is maintained.

The analysis of theoretical foundations of the phenomenon of information security (given modern conditions and prospects of the development of Ukrainian statehood), as well as the results of the historical development of the society, suggest the following conclusions:

1. Information security of the country is a conditions of the state institutions and society, which provides a reliable protection of the national interests of the country and its citizens in the information sphere.

2. The duty to provide information security as an integral part of national security relies on the information organization of the state.

3. The information organization of the state should be the guarantor of the information security of the state and its institutions, society and citizens, stability of the political regime in the situation of globalization processes, growing threats from international terrorism, escalation of the activities of extremist and separatist movements and organizations both within the country and outside it.

4. An urgent scientific and practical task in the sphere of ensuring information security of Ukraine is to achieve a unified approach to determining optimal models and ways of ensuring information security of the state on the basis of determining the most important qualitative and quantitative properties and parameters of this phenomenon. 
Information security is a prerequisite for the existence of individuals, states and society as a whole. Therefore, it is expedient to highlight the following levels of information security:

- level of a person;

- social level;

- state level.

From the point of view of ensuring military security, of greatest importance is the state level on which are conducted:

- information and analytical support of state bodies;

- information support of internal and foreign policy at the interstate level;

- measures to protect the information with restricted access;

- counteracting violations in the information sphere;

- counteracting computer crimes.

It is worth noting that the main task of all measures, aimed at maintaining information security, is minimizing the harm from the following factors: falsity, delay in getting or incompleteness of information, and dissemination of information illegally [8].

The main tasks in providing information security include [9]:

- creation of conditions for securing information sovereignty of the state;

- participation in improving the state regulation of the development of the information sphere by creating regulatory, legal and economic prerequisites for the development of national information infrastructure and resources, introduction of the latest technologies in this sphere, filling the internal and world information space with reliable information about Ukraine;

- creation of conditions for active involvement of the mass media in the struggle against corruption, overuse of the office and other phenomena that threaten Ukraine's national security;

- ensuring a strict observance of the constitutional right of citizens to freedom of speech, access to information, prevention of unlawful interference by public authorities, local self-government bodies, their officials in the activities of the mass media, discrimination in the information sphere and witch-hunt for journalists for political positions;

- taking comprehensive measures to protect the national information space and counteracting monopolization of Ukraine's information sphere;

- ensuring information security of all constituent elements of the public administration system;

- supporting the information-analytical potential of the country;

- realization of state policy of information security;

- conducting active intelligence, counterintelligence and investigative activities in order to provide information security for the development of strategic, 
tactical and operational decisions in the sphere of public information security management and development of mechanisms for their implementation;

- exposure, prevention and suppression of intelligence and other activities of special services, as well as individuals or organizations, aimed at threating the information security of Ukraine;

- exposure, prevention and suppression of information terrorism and other activities aimed at undermining the functioning of the public administration system;

- monitoring (observing, assessing and forecasting) the state of information security in connection with the influence of threats and dangers both from the inside and outside of the public administration system;

- counteracting technical penetration into information systems of public administration bodies for the purpose of committing crimes, conducting sabotage-terrorist and intelligence activities;

- prevention of possible illegal and other negative activity of the subjects of the national security support system from the inside of it;

- securing the system of guarding state secrets;

- organization of democratic civilian control over the functioning of the public administration system, etc.

The implementation of these tasks requires identification and reciprocal systematization of the threats to information security of the state. To this end, this approach is proposed.

As mentioned in [10], the information security is a complex, systemic, multilevel phenomenon. A number of factors have a direct influence on its condition and prospects of development, the most important of which are shown in Figure 1.

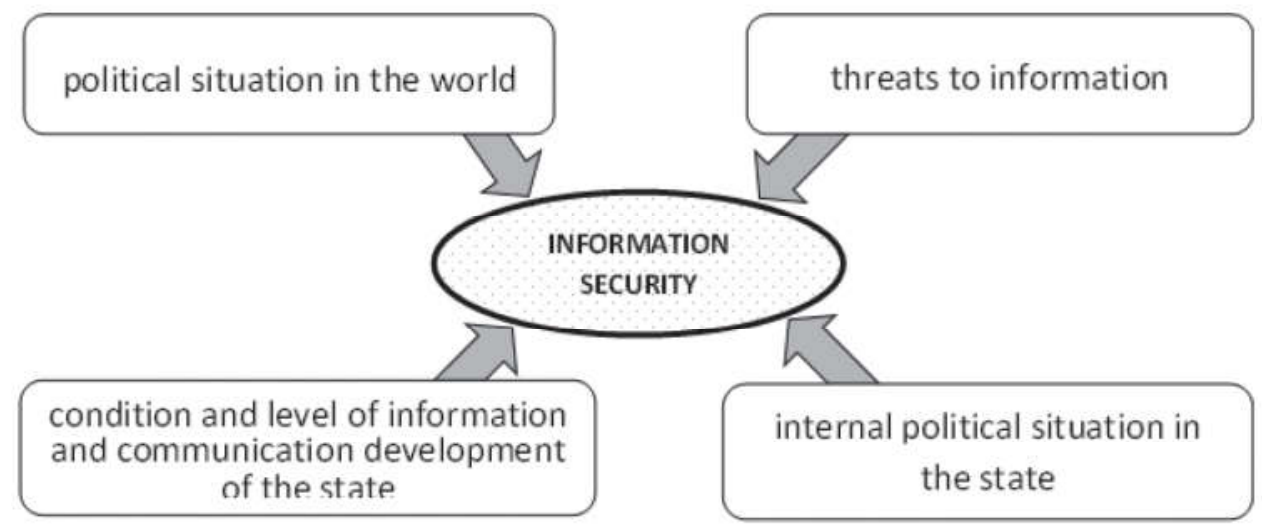

Figure 1 . The main factors influencing the information security of a state 
We propose to systematize threats by the following characteristics:

- direction of the origin (external, internal);

- orientation;

- sphere of manifestation (influence).

External threats to information security include:

- conducting an information war against Ukraine;

- negative external influence on the information space of Ukraine;

- formation by foreign media of a distorted informational picture of the world instead of the real one.

Internal threats are as follows:

- lack of a comprehensive communicative policy of the state, national strategy for the development of the information society in Ukraine and a plan of action for its implementation;

- insufficient amount of competitive national information product;

- critical condition of information and computer systems security;

- vulnerability of objects of critical infrastructure and state information resources to cyber attacks;

- lack of coordination of public and private sectors' efforts to effectively use available resources;

- insufficient development of the regulatory framework of the information sphere;

- a low level of state support for the production of informatization means, software tools and introduction of information and communication technologies;

- physical and moral obsoleteness of the system of guarding state secrets and other types of information with limited access.

In its general direction, the threats to Ukraine's information security can be divided into four types (Figure 2).

The following factors can threaten constitutional rights and freedoms of a person and citizen in the spiritual life and information activity, individual, group and public consciousness, spiritual revival of Ukraine:

- adoption by the state authorities of normative legal acts limiting the constitutional rights of citizens in the sphere of spiritual life and information activity;

- squeezing out of Ukrainian news agencies and media from the internal information market and increasing dependence on foreign information structures;

- creation of monopolies on forming, getting and spreading of information in Ukraine, including with the use of telecommunication systems;

- unlawful use of special means of influencing individual, group and public consciousness; 
- non-compliance with the requirements of Ukrainian legislation regulating relations in the information sphere;

- unlawful restriction of the citizens' access to open information resources, archival materials, other socially important open information;

- disruption and destruction of the system of accumulation, preservation and protection of cultural values, including archives;

- manipulating the information (misinformation, concealment or distortion of information).

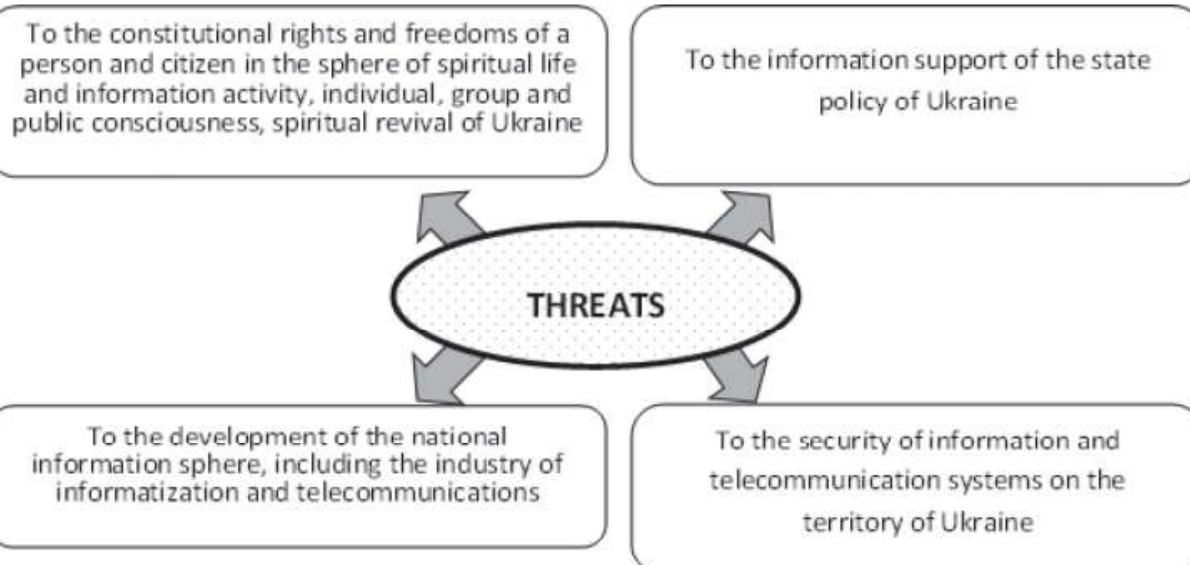

Figure 2. The main threats to the information security of a state

Threats to the information support of the state policy of Ukraine can be:

- low efficiency of information support of the state policy of Ukraine due to the lack of skilled personnel (especially in intelligence agencies), lack of a system in formation and realization of state information policy;

- monopolization of the information market of Ukraine, some of its sectors by domestic and foreign information structures;

- blocking the activities of state mass media to inform Ukrainian and foreign audiences.

Threats to the development of the national information sphere can be:

- counteracting Ukraine's access to the latest information technologies, mutual benefit and equal participation of Ukrainian manufacturers in the global division of labor in the industry of information services, means of informatization, telecommunications, information products, and creating conditions for Ukraine's increasing technological dependence in the sphere of modern information technologies; 
- displacement from the domestic market of Ukrainian manufacturers of information technologies and telecommunications;

- skilled professionals' leaving the country.

Threats to the security of information and telecommunication systems on the territory of Ukraine may be:

- illegal collection and use of information;

- violation of the technology of information processing;

- equipping the hardware and software with components fulfilling functions not provided for by the documentation on these products;

- development and distribution of programs that violate the normal functioning of information and telecommunication systems, in particular information security systems;

- destruction, damage or radio-electronic suppression of means and systems of information processing and telecommunications;

- influence on password-key protection systems of automated information processing and transmission systems;

- compromising keys and means of cryptographic protection of information;

- leakage of information through technical channels;

- interception of information in data networks and communication lines, decryption of this information and imposing false information;

- unauthorized access to the information stored in banks and databases;

- violation of legal restrictions on the dissemination of information.

Information threats can occur in many spheres of national security. Below we will outline the main ones.

In the foreign policy sphere:

- dissemination of distorted, inaccurate and biased information in the global information space that harms Ukraine's national interests and creates a negative image of Ukraine as an unreliable partner for international relations;

- low level of Ukraine's integration into the world information space;

- acts of cybercrime and cyberterrorism threatening the sustainable and safe functioning of national information and telecommunication systems;

- external destructive information influences on public consciousness through the mass media, as well as the Internet;

- use of information space for interference in Ukraine's internal affairs.

In the internal political sphere:

- opacity of political and social activity, which creates preconditions for restriction of freedom of speech, manipulation of public consciousness;

- imperfection of the system of public administration in the information sphere; 
- dissemination of false and biased information to discredit state authorities and destabilize the socio-political situation, which greatly complicates a political decision-making;

- the government, local authorities, media owners, influential public and political figures and businessmen's interference with editorial policy.

In the economic sphere:

- lagging behind of domestic science-driven and high-tech industries, especially in the sphere of telecommunication means and technologies;

- a low level of informatization of the economic sphere;

- unauthorized access to national information and telecommunication networks and systems that could disrupt the work of enterprises, strategically important for the economy, and the safe functioning of the banking and financial system of the state;

- a low level of development of national information infrastructure;

- trends for concentration of ownership and monopolization of segments of the domestic information market, in particular in the sphere of television and radio broadcasting.

In the social and humanitarian spheres:

- destruction of the system of public values, negative changes in their target guidance, harmful impact of information on the mental and physical health of the person;

- Ukraine's lagging behind the developed countries by the level of informatization of social and humanitarian spheres;

- non-observance of human rights and citizen's access to information;

- imperfection of normative legal and technical protection of personal data;

- possibility of unauthorized access to personal data, including in state information resources, their illegal collection, use and distribution;

- weakening of socio-political, interethnic and interfaith harmony in the society, opposing the idea of national unity and unity of the state.

In the scientific and technological sphere:

- decrease in the scientific potential in the field of informatization, communication and information security;

- outflow of scientific personnel and subjects of intellectual property rights abroad;

- insufficient protection against unauthorized access and cyber attacks on information and telecommunication systems;

- uncontrolled expansion of modern information technologies;

- growing advancement of a number of countries and their building up the capacity in counteracting creation of competitive Ukrainian information technologies. 
In the environmental sphere:

- concealment, untimely provision of information or provision of inaccurate information to the public about emergency ecological situations or emergencies of anthropogenic and natural character;

- insufficient reliability of information and telecommunication systems for the collection, processing and transmission of information in emergency situations;

- a low level of informatization of governmental authorities, which makes it impossible to carry out operational control and analysis of potentially dangerous objects and territories, advance forecasting and response to emergencies.

Conclusion. In general, in order to counteract these threats, the activities aimed at ensuring Ukraine's information security should focus on a constructive combination of actions of the state, civil society and a human in four main directions:

- informational and psychological - ensuring the constitutional rights and freedoms of man and citizen, creating favorable psychological climate in the national information space for the establishment of universal and national moral values;

- technological - development and innovative upgrading of national information resources, introduction of the latest technologies in the information's creation, processing, dissemination and protection in information and telecommunication systems;

- protection of information - ensuring its confidentiality, integrity and accessibility in national information resources;

- speeding up the development of information technologies - improving the state's ability to protect against information attacks by third countries, as well as conducting information operations.

So the identified threats to information security and the proposed approach to their systematization will allow in the future to conduct more substantiated research on issues of ensuring information security of the state, in particular, to substantiate the basic requirements for an advanced system of information support to Ukraine's military security.

\section{REFERENCE LIST:}

1. BARINov A., Information Sovereignty or Information Security? [Информационный суверенитет или информационная безопасность?], [in:] A. Barinov, "National Security and Defense", 1(2001), 70-76.

2. Векетоv N., Information Security of the State Development [Информационная безопасность развития государства], Moscow 2004.

3. Halaka O., A System of Views on Scientific and Methodological Foundations of Intelligence Activities in the Context of National Security [Система поглядів на науково-методичні 
засади розвідувальної діяльності у контексті забезпечення національної безпеки], „Strategic Panorama”, (3)2006, 168-172.

4. Information Security. Collection of Articles, (2009), [Информационная безопасность. Сборник статей], Moscow.

5. Kostyukhin A., Ed., Current Military Aspects of Ensuring International Information Security [Актуальные военные аспекты обеспечения международной информационной безопасности], Moscow 2008.

6. LIPKAN V., Information Security of Ukraine During Its European Integration [Інформаційна безпека України в умовах євроінтеграціi], V. Lipkan, Yu. Maksymenko, V. Zhelikhovskyi, Kyiv, KST 2006.

7. Lopatin V., Information Security of Russia: Man, Society, State [Информационная безопасность России: Человек, общество, государство], Moscow 2000.

8. Permyakov O., Sbitnyev A., Information Technologies and Modern Armed Struggle [Інформаційні технології і сучасна збройна боротьба], Luhansk, Znannya 2008

9. Romanchenko I., Basic Aspects of Information Support to Military Security of the State [Основні аспекти інформаційного забезпечення воєнної безпеки держави], [in:] I. Romanchenko, V. Hvozd, Collection of articles, Works of the Central Scientific Library of the Ukrainian Armed Forces, Kyiv (2015), Issue 1(71), 18-25.

10. Tоцивко V., Conceptual Foundations of Ukraine's Information Security, [Концептуальні основи інформаційної безпеки України], [in:] V. Tolubko, S. Zhuk, V. Kosevtsov, „Science and Defense” 2(2004), 19-25.

\section{SYSTEMATYZACJA ZAGROŻEŃ DLA BEZPIECZEŃSTWA INFORMACYJNEGO PAŃSTWA2}

Streszczenie. W ostatnich kilku latach Ukraina stawiała czoła wpływom innych państw zainteresowanych pozyskiwaniem newralgicznych informacji. W związku z tym istotna stała się kwestia identyfikacji i usystematyzowania zagrożeń dla bezpieczeństwa informacji państwa, a także sposobów przeciwdziałania im. Artykuł identyfikuje i systematyzuje zagrożenia dla bezpieczeństwa informacji w skali narodowej i proponuje główne kierunki przeciwdziałania zagrożeniom.

Słowa kluczowe: bezpieczeństwo informacji, wsparcie informacyjne, wojna informacyjna, bezpieczeństwo militarne, sfera bezpieczeństwa i obrony, systemy telekomunikacyjne, zagrożenia, Ukraina.

2 Autorzy - prof. I.S. Romanchenko, dr V.I. Hvozd i dr płk. O.I. Solomitsky są wykładowcami nauk wojskowych oraz analistami Borysfen Intel - Niezależnego Centrum Analitycznego Studiów Geopolitycznych na Ukrainie (borysfenintel@gmail.com). 